\title{
Oil wealth; meat in Norway, poison in Nigeria: An analysis of human capital as a transmission channel of resource curse
}

\author{
Adebiyi Oyeyemi Omodadepo, ${ }^{1,}$, Olomola Philip Akanni \\ ${ }^{1}$ Department of Economics Accounting and Finance, College of Management Sciences, Bells University of Technology, Ota, Ogun State, \\ Nigeria \\ ${ }^{2}$ Department of Economics, Faculty of Social Sciences, Obafemi Awolowo University, Ile-Ife, Osun State, Nigeria
}

\section{Email address:}

realyemmy@yahoo.co.uk(A. O. Omodadepo),polomola@yahoo.ca(O. P. Akanni)

\section{To cite this article:}

Adebiyi Oyeyemi Omodadepo, Olomola Philip Akanni. Oil Wealth; Meat in Norway, Poison in Nigeria: An Analysis of Human Capital as a Transmission Channel of Resource Curse. Journal of World Economic Research. Vol. 2, No. 3, 2013, pp. 39-44.

doi: $10.11648 /$ j.jwer.20130203.12

\begin{abstract}
The study examined the resource curse hypothesis on Nigeria, an oil rich but poor country and Norway, an oil rich and rich country. Human capital was the transmission channel explored in this study. The VAR was used to test annual data from 1970-2007. The result showed that oil wealth led to economic growth in both countries. Oil wealth led to improve human capital in Norway, but led to negative human capital in Nigeria. Our result is not consistent with our expectation yet human capital remains as a transmission channel to growth in both countries. Also, a long run relationship exists among oil wealth, human capital and economic growth for both countries.
\end{abstract}

Keywords: Resource Curse, Oil Wealth, Human Capital, Economic Growth

\section{Introduction}

The resource curse argument says that natural resource rich countries tend to grow at a slower pace while countries with little or no natural resources grow at a faster rate. Revenue received from natural wealth should generate economic progress and bring wealth to a resource rich country. However, economic realities and empirical studies seem to be at variance with theoretical explanations. Many resource rich countries appear to have experienced a worse performance in terms of economic progress and poverty reduction than countries without such apparent "benefits" (Stevens, 2003). while some cross country studies establish only a statistical connection between large resources and poor economic growth ( Sachs and Warner 1997, 2001; Blute, Damania and Deacon 2005), other international empirical evidence rather identified a negative or at best not causal relationship between large resources and economic growth (Maloney, 2002; Wright and Czelusta,2002; Mehlum, Moene and Torvik, 2008). Such empirical confusion is worrisome especially for individual oil producing countries.

For example, Nigeria is the eight largest producer of oil in the world, the sixth country with the largest reserve of natural gas and has the largest bitumen deposit in the world (Soludo, 2006). Yet the country remains poor as one out of every three Nigerian lives in abject poverty, with the infrastructure of the country only fairly developed (7 seaports, 6 international airports etc) and the average GDP rate was 3\% for a decade i.e. 1990-1999 (National Planning Commission; 2007). Contrarily, Norway ranks today as the world's third largest exporter of oil after Saudi Arabia and Russia. According to the UNDP human capital development indicator, Norway is currently ranked among the countries with the highest GDP per capita (GDP per capita was $\$ 42,000$ in 2005) and one of the countries providing the highest welfare for its populace (Mehlum, Moene and Torvik, 2008).

However, some scholars (Gylfason 2000, Stevens 2003, Manning 2002) are of the view that the presence of oil itself may not be the determining factor for growth; rather it may be the transmission channel of oil wealth that determines growth. Manning 2004, argued that natural resources themselves are not detrimental to economic development rather, resource abundance often causes distortion (that serves as transmission mechanisms) which 
undermines economic performance. There exists today different transmission channels of natural wealth to economic growth, this study focused on human capital channel. Human capital represents the investment people make in themselves that enhance their economic productivity (Olaniyan and Okemakinde, 2008), that is, it represents skills and knowledge of workers. More and better education is a prerequisite for rapid economic development around the world. Education stimulate economic growth and improves people's live through many channels: by increasing efficiency of labour force, by fostering democracy thereby improving good governance, by improving health, by enhancing equality and so on (Gylfason; 2000). However, the central issue is; both Nigeria and Norway are oil abundant countries, yet Norway's economy is developed while Nigeria's economy is developing. Could it be developed human capital that made Norway to escape the "curse"? Conversely, could it be the underdeveloped human capital that made oil wealth not to transit into growth in the Nigerian economy? Hence, this study examines empirically the role of oil wealth on human capital and economic growth in Nigeria and Norway that have not been exploited in the literature.

The second section discussed the review of related literature and the conceptual framework, section three discusses the data, shows the analyses, and the result. Section four discussed the summary and conclusion.

\subsection{Literature Review}

Most studies conducted on oil wealth and growth relationship in the Norwegian economy are cross country studies. Country specific studies are rare. Most empirical analysis found that Norway has escaped the "resource curse" (Gylfason 2000; Gylfason and Zoega,2001 ; Stevens 2003; Papyrakis and Gerlagh 2003; Mehlum, Moene and Torvik2002; Bornhorst, Gupta and Thornton, 2008).Mehlum, Moene and Torvik (2008) carried out a study on mineral rent and social development in Norway. They maintained that natural resources in Norway kept the economy growing because oil discovery stimulated productive forces rather than grabber activities. This was as a result of high quality of institutions and technological changes of oil extraction offshore. In their opinion countries with resource curse must clean up their institutions and increase their saving.Cappelen and Mj0set (2009) attribute the development in the Norwegian economy to the growth of their petroleum sector. This is contrary to the resource curse hypothesis. They used crosssectional model to analyze the variables used by Sachs and Warner (1999) as well as Mehlum, Moene and Torvik (2006). Also, they used Nordic model to make comparism among the Nordic countries since they are all developed. It was concluded that the development success of Norway can be attributed to good institutional quality and good and adequate policies.

Much study has not been carried out on natural resources and growth nexus in Nigeria. Olomola and Adejumo (2006) examined the effect of oil price shock on output, inflation, the real exchange rate and money supply in Nigeria. They employed the Vector Auto-Regressive method in analyzing quarterly data for Nigeria from 1970 to 2003.They found that fluctuations in oil prices do significantly influence real exchange rates. Their study revealed that a high real oil price may give rise to wealth effect and appreciate the real exchange rate which may squeeze the tradable sector leading to "Dutch Disease" existence in Nigeria. .Olomola and Adejumo (2006) focused on oil rents and trends of revenue allocation to the educational sector in Nigeria for a 27 year period (1977 - 2003). Using VAR as their estimation method, they found that the benefits in the oil sector did not affect government spending on education positively. The scholars also compared government spending patterns on education between Nigeria Botswana and Zimbabwe, which are non-oil exporting countries. They found that the governments of both Botswana and Zimbabwe spend more on education compared to Nigeria.

Oyefusi (2007) examined oil dependence and civil conflicts in Nigeria. His focus was on economic dynamics of resource- induced conflict by identifying two dimensions to oil related civil conflict in Nigeria. The first is violent rent seeking political violence linked to excessive government dependence on oil revenues, an institutionally unstable revenue allocation system, corruption and weak political institutional arrangement. The second is the Niger Delta crisis which is mainly attributed to poor institutional arrangement. The author used multinominal logit and order logit modelling approaches to analyze data on variables like civil disobedience, violence and education. He concluded from his analysis that three factors consistently explain the propensity to general violence among individuals. Odularu (2008) analyzed the relationship between crude oil sector and the Nigerian economic performance. He used OLS to analyze data for the period 1970-2005. He maintained that crude oil consumption and export has contributed to the improvement of the Nigerian economy in areas such as employment creation, contribution to government revenue, GDP and foreign reserves. However, he concluded that crude oil has not significantly improved economic growth in Nigeria due to corruption and poor administration.

Sala-i-Martin and Subramanian (2003) used cross section empirical analysis to demonstrate that stunted institutional development (this includes corruption, weak governance rent-seeking and plunder) is a problem intrinsic to countries that own natural resources such as oil or minerals. Their result showed that oil exerts a negative and nonlinear impact on economic growth in Nigeria. They also said waste and corruption from oil rather than Dutch disease has been responsible for Nigeria's poor long run economic performance. The authors focused on institution and Dutch disease as the only transmission channel of oil wealth to economic growth in Nigeria. They neglected investment channel as a transmission channel to economic growth. This study seeks to contribute to existing literature by 
comparing two countries having a common natural resource but different growth rate.

\subsection{Conceptual Framework}

There are several channels through which natural resources could affect the growth of an oil abundant country. While empirical evidence (Sala-i-matin and Subramania,2003; Olomola and Adejumo, 2006; Olomola, 2007) strongly supports the existence of resource curse in Nigeria, Norway seems to have escaped the "curse" (Gylfason and Zoega, 2001; Mehlum, Moene and Torvik, 2008).The underlying transmission mechanisms remain controversial. In view of the controversy as regards the merits or otherwise of each of these channels, the study focuses on human capital as the transmission channel of oil wealth to economic growth in both economies. To this end, the study adapted the framework of Manning (2005) and Olomola(2007) as used by Adebiyi (2013). The framework is captured in Figure 1 below.

According to figure 1 , oil wealth can transmit to economic growth directly through the factors of production and indirectly through transmission channels. The emphasis of this work is on human capital channel. If oil abundant countries invests less in human capital (both health and education), the returns may be low productivity. Low productivity will be reflected in other indicators like low life expectancy and this in turn may impair growth.

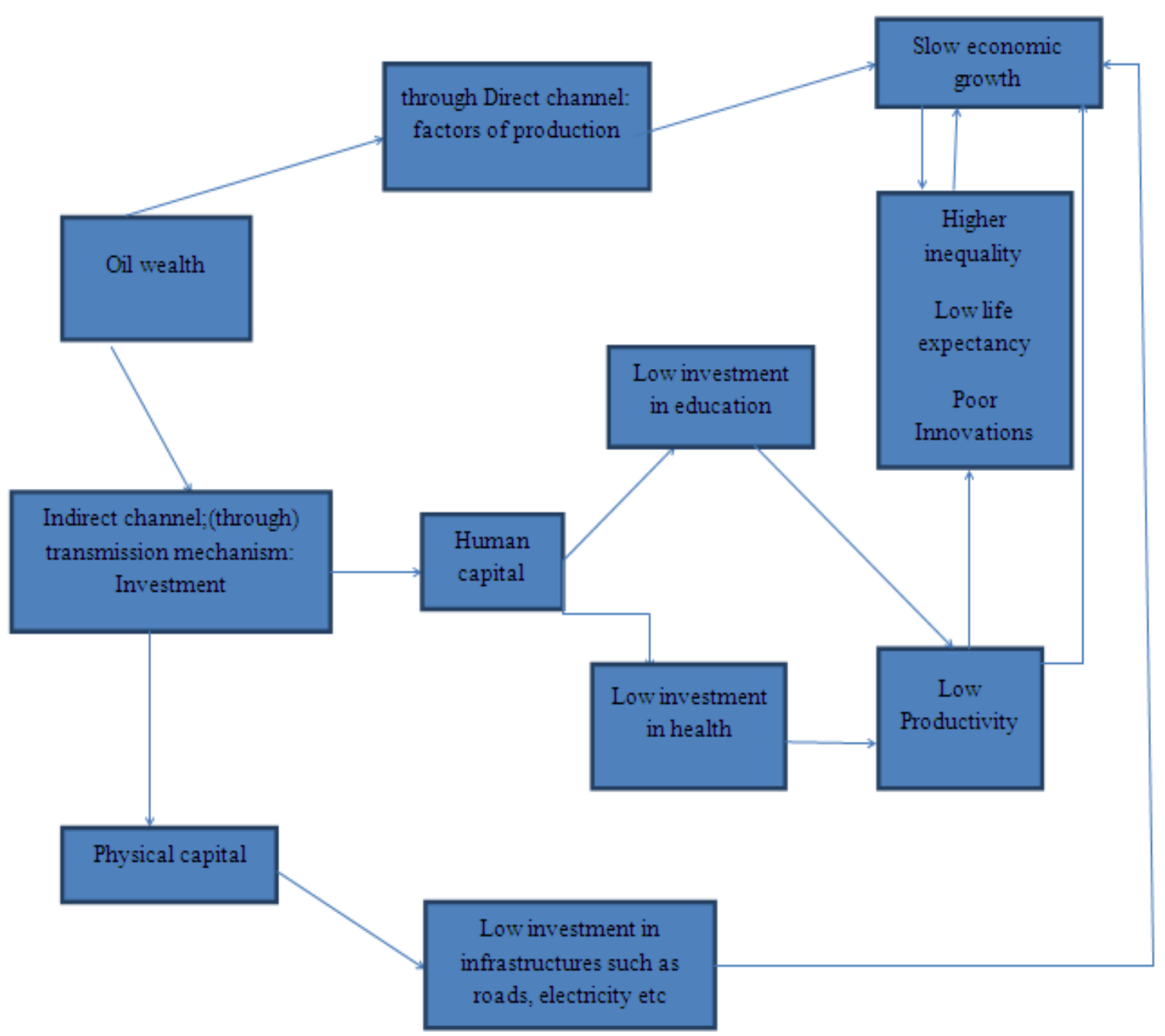

Source: Adapted from Manning (2005) and Olomola (2007)

Figure 1. Transmission Mechanism of Oil Wealth to economic growth

\subsection{Data}

This study employed annual for the period 1970 to 2007 obtained from World Development Indicator published by the World Bank, the Central Bank of Nigeria Statistical Bulletin and statistical data published by the Bank of Nords.Surely, oil wealth is not synonymous to natural resources but in Nigeria as well as Norway, oil exploration dominated natural resource contribution. Indeed, it constitutes a huge percentage of natural resource contribution to the economy and hence, development in the oil sector can sufficiently reflect the overall natural resource impact on the economies. The time frame is carefully selected to cover the period when serious oil 
exploration began in Nigeria. Although crude oil was discovered in commercial quantities in Nigeria in the mid1960s, the civil war of 1966 to 1969 affected full exploration of the vast oil resources in the oil rich areas which was coincidentally where the civil war was more pronounced. Similarly, crude oil was discovered in Norway in the 1960s but exploration started in 1973. This period is considered long enough to reflect the effects of the fastchanging economic atmosphere in international oil market in general and particularly in both countries. Oil abundance and human capital are explanatory variables and real grossdomestic product as the dependent variable. Human capital variablecomprises of government expenditure on health and government expenditure on education.

\subsection{Analyses}

We began the analyses by testing the time series properties of the data. We employed Augmented DickeyFuller (ADF) test as explained in Engle and Granger (1987) and Phillips-Perron test. This development arises from the prevalence of substantial co-movement among most economic time series data, which has been argued in the literature as undermining the policy implications that could be inferred from such modelling constructs. (Engle and Granger, 1987).

Table 1. Determining the order of Integration

\begin{tabular}{lccc}
\hline Variables & $\begin{array}{c}\text { Augmented } \\
\text { Dickey-Fuller }\end{array}$ & $\begin{array}{c}\text { Phillips- } \\
\text { Perron }\end{array}$ & $\begin{array}{c}\text { Order of } \\
\text { Integration }\end{array}$ \\
\hline RGDPN & -3.9345 & -5.6347 & 1 \\
RGDPW & -4.2910 & -5.9871 & 1 \\
01LN & -5.0393 & -5.6295 & 1 \\
OILW & -7.0923 & -6.0353 & 1 \\
HUMN & -4.5454 & -8.8048 & 1 \\
HUMW & -6.8570 & -12.9834 & 1 \\
\hline
\end{tabular}

Note: All the variables are statistically significant at $1 \%$ and $5 \%$ levels Source: Author's computation.

The results of the unit root tests on variables as shown in the table above revealed that all the variables are integrated in order of one at one per cent significant level. Thus, all the variables are stationary at first difference. We further to testing for cointegration, since all variables are I(1) series. We employed this in order to assess the long run relationship of oil, human capital and economic growth in Nigeria and Norway. A cointegration test in line with Johansen test was conducted.

Table 2. Johansen Cointegration Test for Nigeria.

\begin{tabular}{ccccc}
\hline $\begin{array}{c}\text { Hypothesize } \\
\text { d No.ofCE(s) }\end{array}$ & Max-Eigen & Likelihood & \multicolumn{2}{c}{ Critical Values } \\
\hline None** & 0.9994 & 308.0612 & 35.65 & 29.68 \\
Almost 1** & 0.8128 & 61.0701 & 20.04 & 15.41 \\
At most 2* & 0.1604 & 5.7699 & 6.65 & 3.76 \\
\hline
\end{tabular}

Source: Author's computation.

Max-Eigen and Likelihood Ratio Statistic tests indicate 3 cointegrating equations at $1 \%$ and $5 \%$ level. $*(* *)$ denotes rejection of the hypothesis at the 5\% (1\%) level.

Table 3. Johansen Cointegration Test for Norway.

\begin{tabular}{lllll}
\hline $\begin{array}{l}\text { Hypothesized } \\
\text { No.ofCE(s) }\end{array}$ & $\begin{array}{l}\text { Max-Eigen } \\
\text { Statistic }\end{array}$ & $\begin{array}{l}\text { Likelihood } \\
\text { Ratio }\end{array}$ & Critical Values \\
\hline & & & $1 \%$ & $5 \%$ \\
None** & 0.9934 & 258.9657 & 35.65 & 29.68 \\
At most 1** & 0.8902 & 93.5053 & 20.04 & 15.41 \\
At most 2** & 0.4645 & 20.6093 & 6.65 & 3.76 \\
\hline
\end{tabular}

Max-Eigen and Likelihood Ratio Statistic tests indicate 3 cointegrating equations at $1 \%$ level. $*(* *)$ denotes rejection of the hypothesis at the $5 \%(1 \%)$ level.

From table 2 and 3 above, the results show that both the maximum Eigen value and likelihood statistic suggest the presence of three cointegrating equation among the three variables in both Nigeria (at 5 percent level) and Norway (at 1 percent level) in line with the Osterwald-Lenum critical values. This unveils the existence of a long-run equilibrium relationship among economic growth, oil wealth and human capital in the two countries.

We proceed to compute Vector Autoregression VAR for both Nigeria and Norway in tables 4 to 7 . Tables 4 and 5 shows the transmission channel while tables 6 and 7 brings all the variables together.

Table 4. Vector Auto regress ion Estimate

\begin{tabular}{llll}
\hline Variable & Coefficient & Standard Error & t-ratio \\
\hline C & 2592,735 & 2427.94 & 1.0678 \\
OILN(-1) & 0.8752 & 0.1483 & $5.8982 * *$ \\
HUMN & -0.4638 & 2.5056 & $-0.1851^{*}$ \\
R2 & 0.67 & F-statistics & 24.9862 \\
Adjusted R2 & 0.64 & & \\
\hline
\end{tabular}

(VAR) for Nigeria.

$(* *) *$ indicate significance at (10\%) 5\%.

Table 5. Vector Auto regression Estimate (VAR) for Norway

\begin{tabular}{llll}
\hline Variable & Coefficient & Standard Error & t-ratio \\
\hline C OILW(-1) & 43.9779 & 46.3006 & 1.0678 \\
& 0.8050 & 0.1220 & 5.8982 \\
HUMW & 0.0327 & 0.0236 & $-0.1851^{*}$ \\
R2 & 0.68 & F-statistics & 26.4507 \\
Adjusted R2 & 0.66 & & \\
\hline
\end{tabular}

$(* *) *$ indicate significance at $(5 \%) 1 \%$.

Table 6. Vector Autoregression Estimate (VAR) for Nigeria

\begin{tabular}{llll}
\hline Variable & Coefficient & Standard Error & t-ratio \\
\hline C & 190.3831 & 116.404 & 1.6355 \\
RGDPN(-1) & 0.7234 & 0.2045 & $3.5373^{*}$ \\
RGDPN(-2) & 0.0602 & 0.1647 & $0.3655^{*}$ \\
HUMN & -0.0406 & 0.0149 & $-2.7097^{*}$ \\
OILN & 0.0021 & 0.0010 & $2,0556^{*}$ \\
R" & 0.85 & F-statistics & 30.0254 \\
Adjusted R & 20.82 & & \\
\hline
\end{tabular}

$(* *) *$ indicate significance at $(5 \%) 1 \%$. 
Table 7. Vector Autoregression Estimate (VAR) for Norway

\begin{tabular}{llll}
\hline Variable & Coefficient & Standard Error & t-ratio \\
\hline C & 960.4632 & 597.4632 & 1.6073 \\
RGDPW(-1) & 1.4562 & 0.1874 & 7.7687 \\
RGDPW(-2) & -0.4833 & 0.1892 & $-2.5541^{*}$ \\
HUMW & 0.0854 & 0.1527 & $0.5597^{*}$ \\
01LW & 0.0855 & 0.9332 & $0.0933^{*}$ \\
R2 & 0,99 & F-statistics & 745.3444 \\
Adjusted R2 & 0.99 & & \\
\hline
\end{tabular}

$(* *) *$ indicate significance at $(5 \%) 1 \%$.

In Nigeria, growth variable was lagged twice and the result is statistically significant at 5\%. Human capital variable is negatively signed while oil variable is positively signed. The sign seemed to be consistent with resource curse hypothesis. For Norway, the first growth variable lag is positive but it is not statistically significant at $5 \%$ level. The second growth variable lag is negative but statistically significant at 5\% level. Oil and human capital variables are positively signed. The result is consistent with our expectation that it could be the developed nature of human capital and oil variables that lead to economic growth in Norway.

\section{Summary and Conclusion}

This study examined the "Resource Curse" hypothesis on the economy of both Nigeria and Norway. The study hypothesized that Nigeria, a developing country, may be suffering from resource curse as a result of its underdeveloped human capital. While Norway a developed country may have escaped the curse through a developed human capital. We employed recent development in time series econometrics to analyze the variables. The resultant model appears robust and could be used to draw some policy lessons. It was found that oil wealth, human capital and economic growth long run relationship in both countries. The VAR reflects that oil wealth decreases human capital in Nigeria while in Norway oil wealth leads to increase in human capital. Although the co-efficient of economic growth is positively signed in Nigeria (contrary to our expectation), this suggests that the resource curse does not really exist; yet human capital development stands as a transmission channel seems to exist. In Norway, all the variables are positively signed, suggesting that the country has escaped the curse.

\section{References}

[1] Blute, E., Damania, R. and R. Deacon (2005), "Resource Intensity, Institution and Development", WorldDevelopment 33, (7), pp 1029-1044.

[2] Budina, N. Winbergen, W. (2008), "Managing Oil Revenue Volatility in Nigeria: The Role of Fiscal Policy"AFRI _ 427 - 460qxd.
[3] Cappelen, A, and Mj0set, L. (2009), "Can Norway be a Role Model for Natural Resource Abundant Countries?", UNOWIDER, 2009/23.

[4] Cobbe, J. (1999), "An African miracle state class leadership and colonial legacy in Botswana development," A book review of Samatar, A.(1999). Journal of African Historical Study, 32 (I).

[5] Gylfason, T. (2000), "Natural Resources, Education and Economic Development," European Economics Review, 45: $847-859$.

[6] Gylfason, T. and Zoega, G. (2001). "Natural Resources and Economic Growth: The Role of Investment"

[7] Manning, A. (2002). "Human Capital as Transmission Mechanism of the Resource Curse," The Park Place Economists, XII.

[8] Manning, A. (2004). "The Resource Curse Revisited". Department of Economics, Illinois Wesleyan University.

[9] Marktanner, M. and Nasr, J. (2006), "From Rentier State and Resource Curse to even Worse". American University ofBeirute Institute of Financial Economics, $(3,2006)$.

[10] Maloney, W. (2002), "Innovation and Growth in Resource Rich Countries," Central Bank of Chile Working Papers, (148 February), Central bank of Chile.

[11] Mehium, H., Moene, K. and Torvik, R. (2002), "Institution and Resource curse," Department of Economics, University of Oslo.

[12] Mehium, H., Moene, K. and Torvik, R. (2008), "Mineral Rents and Social Development in Norway" Department of Economics, Norwegian University of Science and Technology.

[13] National Planning Commission (2007), "Nigeria Millennium Development Goals, 2006 Report”.

[14] Odularu, G. (2008), "Crude Oil and the Nigerian Economic Performance," Oil and Gas Business.

[15] Olaniyan, D. and Okemakinde, T. (2008), "Human Capital Theory - Implications for Educational Development, European Journal Economics Incorporated.

[16] Olomola, P.A.(2007), "Oil Wealth and Economic Growth in Oil Exporting African countries," AERC Research Paper 170.

[17] Olomola, P. and Adejumo, V. (2006), "Oil Price Shock and Macroeconomic Activities in Nigeria." International Research Journal of Finance and Economics.

[18] Olomola, P. and Adejumo, V. (2006), "Oil Wealth, Government Spending on Education and Economic Growth in Nigeria," Ife Social Science Review, 20, 2006 (1), 1-12.

[19] Olusi, J. and Olagunju, M. (2005), "The Primary Sector of the economy and the Dutch Disease in Nigeria" The Pakistan Development Review, 44 (2), 2005.

[20] Oyefusi, A. (2007). "Oil Dependence and Civil Conflict in Nigeria” CSAE WPS/2007-09

[21] Papyrakis, E. and Gerlagh, R. (2003), "The Resource Curse Hypothesis and its Transmission Channels" Journal of Comparative Economics, 32(2004) 181-193. 
[22] Sachs, I. and Warner, A. (1995), "Natural Resource Abundance and Economic Growth," National Bureau of Economic Research, 5398, Cambridge, M.A.

[23] Sachs, I. and Warner, A. (1997), "Sources of Slow Growth in African Economies," Journal of African Economies 6 (3), 335-376.

[24] Sachs, I. and Warner, A. (2001), "Natural Resources and Economic Development; The Curse of Natural Resources,"
European Economic Review, 45 (2001), 827-838.

[25] Sala-i-martin, X. and Subramania, A. (2003), "Addressing the Natural Resource Curse: An Illustration from Nigeria"

[26] Soludo, C. (2006). "Beyond Banking Sector Consolidation in Nigeria," National Economic Summit, 2006

[27] Stevens, P. (2003). "Resource Impact - Curse or Blessing? A Literature Survey," Centre for Energy, Petroleum and Mineral Law and Policy, University of Dundee. 